\title{
To check the socio-economic importance of honey bee for developing countries in current financial crisis
}

Sanam Naz ${ }^{1 *}$, Muhammad Faheem Malik ${ }^{1}$, Mubashar Hussain ${ }^{1}$, Razia Iqbal $^{1}$ and Sumera Afsheen ${ }^{1}$

1. Department of Zoology, University of Gujrat, Hafiz Hayat Campus, Gujrat, Pakistan

*Corresponding author's email: sanam.naz2016@gmail.com

Citation

Sanam Naz, Muhammad Faheem Malik, Mubashar Hussain, Razia Iqbal and Sumera Afsheen. To check the socioeconomic importance of honey bee for developing countries in current financial crisis. Pure and Applied Biology. Vol. 11, Issue 3, pp851-860. http://dx.doi.org/10.19045/bspab.2022.110087

Received: 13/09/2021

Revised: $26 / 12 / 2021$

Accepted: 29/12/2021

Online First: $31 / 12 / 2021$

\section{Abstract}

This review is done for elaborating social and economic importance of honey bees. Honey bees are imperative natural source of many products including Honey, wax, and Royal jelly. Beside this their role in ecosystem is very astonishing including pollination service that is very obligate for our food production as well as earning from agriculture sector. Beekeepers manage the honey bees either for bee products or for pollination but principally their main endeavor is earning. Apiculture can generate enormous revenue for developing countries especially for rural population in present financial crisis. For this reason, good beekeeping practice, skill and bee disease management is required for better production. Women can also run this business as a helping hand with men. If we emphasis on this ecofriendly culture, we not only conserve honey bees and stable ecosystem, but we can increase profit as well.

Keywords: Beekeeping or Apiculture; Bees Declining; Earning Source; Honey Bee; Income source; Pollination

\section{Introduction}

\section{Importance of Honey bee}

Honey bees (Apis mellifera) are cosmopolitan specie and belong to order Hymenoptera. Approximately 26 sub-species of honey bees are found. These are social insects that live in colonies and about 60,000 individuals present in each bee colony. Each colony contains a single queen that lay eggs, 10,000 of female workers who work for the endurance and wellbeing of colony and drones who fertile the virgin females [1]. Bees species are native to Asia, Europe, Africa and also found in deserts, mountains, savanna and grasslands etc [2]. Honey bees has high adaptation capacity and successfully acclimatize to different World's region [3] Bees services largely depend upon the species richness and abundance [4]. Our society receives thousands of benefits from honey bee products. And, we get countless additional ecological benefits from these tiny creatures [5].

Honey, Propolis, Bee wax and Royal jelly Honey bees are the greater chemist and engineers that manufacture valuable products (such as natural honey, bee wax, propolis, royal jelly etc) for this reason they are 
managed globally. Honey, wax, propolis and some other bee products are used as food and in treatment of many diseases [6-8]. In past, honey was a natural sweetener throughout the world at the place of sugar later, the refinement method of sugar is developed but we cannot challenge its importance still now [9]. It also has strong religious background Holy Qur'an that is the Holy book of Islam has Surah al-Nahl whose meaning is Chapter of Honey bee which shows the importance of honey as food and medicines. Even Prophet Muhammad (PBUH) emphasizes the importance of honey for restorative and curing purpose in a Hadith $[7,10]$. Honey is formed by nectar, pollen and honeydew that are collected by worker bees from different flowers [11-13]. Honey has complex composition. The quality of honey varies due to different sources of raw materials and storage conditions. Natural honey act as a nutraceutical agent both ancient and modern time because it has such composition which is associated with antioxidant, antimicrobial, anti-inflammatory, antiseptic, anticancer, and wound repairing properties [10, 12-17]. Honey consider as a second currency in Soviet bloc countries. Therefore, large numbers of people of this country are bee keepers [18]. Global honey production in 2007 is about 1.07 million metric tons that is 58\% increase since 1961 [9] Apis mellifera collect resins from different plants and use it as a propolis. It is very important bee product that used for treatment of different human diseases due to antimicrobial activities including treatment of HIV-1 virus [19]. Bee wax is very important product which is used for making different products. Similarly, royal jelly has its own significance [9]. It has anti-inflammatory, anti-tumor, anti-fatigue, anti-leishmanial, moisturizing, emulsifying and many other properties due to which it is used for the treatment of many human diseases including some parasitic diseases and used in cosmetics for beauty purpose [7,
20, 21]. Honey bee larvae serves as a source of protein [10].

Bee venom therapy

Bee venom has 18 pharmacologically active components. It is used in a venom immunotherapy for the treatment of arthritis, back pain, sciatica, multiple sclerosis etc but its effectiveness depends upon the venom dose, exposure time to venom and the type of venom. But some time bee venom immunotherapy will fail due to some venom complications or some other reasons [8, 22].

\section{Pollination}

There is a great demand of honey bees for pollination service [23] without pollination there will be no more plants and crops on earth. Pollination is very important regulating, supporting and cultural ecosystem service [24, 25] for conservation of plants, animal's biodiversity and crop productivity [26, 27]. Almost 90\% flowering plants including many crops depend upon animal pollinators for pollination [28] and bees pollination service is about $>66 \%$ out of 15 , 00 crop species [29]. Honey bees are principle species that plays an important ecosystem service as crop pollinators and world widely they remain as economically valuable pollinators $[6,30-34]$. According to an estimation honey bee provide pollination services for up to 90-130 crops [35]. Honey bees are cheap, versatile, and easily available as compared to other pollinators [30]. Globally $65 \%$ food is produced independently by animal pollination and $15 \%$ to $30 \%$ or approximately $35 \%$ human food is produced by these pollinators without them our food might be in a grave jeopardy $[6,18$, 32]. In a previous study it is concluded that in a single visit honey bee pollination produced three seeds [6]. But currently, global pollination service is declining $[6, \mathbf{6}, \mathbf{1 8}$ ] recently a study [36] showed that by loss of natural habitat and use of excessive pesticides minimized the visit of bees to that area resulting into excessive declining of 
pollination. Same decline was observed in Europe and in USA [33, 37] known as "pollination crisis" [38] which is a great threat to the agriculture sector. Therefore, there is a huge recent interest of scientists, politicians, media and public towards pollinators. There is guarantee of pollination if only bees are in large number [31, 33, 39]. So, we can manage the pollination service by inputting of honey bee as pollinator with wild pollinators [28]. Although, humans will not decline with the extinction of honey bees but still world widely they are important pollinators for human food security $[18,40]$ so, in future there is enormous need of these pollinators due to rising stipulate of food for mankind [37, 41]. Honey bees are very accommodating for native crop pollination e.g. water melon that require huge pollination prerequisite [29]. In some countries pollination service is provided at rent at prescribe rates to farmers especially for crops such as Almond, Sunflower, Canola (seeds), Grapes, Apples, Sweet cherries, Watermelons, Avocados etc. [35].

\section{Beekeeping or apiculture}

Apiculture is the management of bee colonies by humans for the production of honey and other honey bee products such as bee wax, natural honey propolis, cerume, royal jelly etc. $[10,11,42]$. It is an activity for economic gain, safeguarding and conservation of environment that is day by day flourishing for rural development $[2,43]$ it's very important source of income for rural areas $[11,44]$. In Saudi Arabia 9000 tons honey is produced from more than one million colonies maintains by 5000 beekeepers annually [45]. In a study, it is concluded that the first aim of $100 \%$ beekeepers is to produce honey. Minimum about $20 \%$ aims have to produce other products and about $50 \%$ beekeepers are aware about pollination service of bees and its importance [24]. Bees are the only organisms which have no competition with other animals for nectar [11] But shortage of raw material is main problem for this subsector's development. It is very important to estimate the carrying capacity of an area for foraging behavior of honey bees because beekeeping depends upon the availability of maximum production of nectar, pollen, water and suitable climatic conditions $[\mathbf{4 5}, 46]$ Optimum temperature for rearing process is $34.5^{\circ} \mathrm{C}$ [46]. For this reason, beekeepers move their colonies for better sources. Productivity depends upon the sources and minimum competition among bees for this there should be optimum distance between apiaries [45, 46]. In case of pollinators declining beekeepers play a major role by providing pollination service. Some crops require small number of pollinators therefore honey bees are very significant for those crops [24]. In developing countries those areas which have infertile soil and low productivity by agriculture sector especially rural areas resulting into food shortage so, for this reason they have enormous focus on nonagriculture activities such as beekeeping [11, 47] on tall wild trees for improving their income, livelihood and conserve the plants. Such type of beekeeping practice is very common in Zimbabwe. Successful beekeeping practice depend upon the modern methods of rearing in which moveable strong hives, healthy bees, good location and use of various miticides or other treatments for decreasing the mortality rate which is the evolution from traditional methods. Some activities are unfriendly for environment and are prohibited by Government, but beekeeping is eco-friendly practice and quick source of income with less investment [11, 61]. Women also participate with men in apiculture activities in different ways such as by cleaning, watering, in management [42]. There should be all information about good beekeeping practice for beekeepers. For information there are lots of web links which give good guidelines to beekeepers. Some links are given below in (Table 1). 
Table 1. Some national and international Beekeeping organizations

\begin{tabular}{|c|c|}
\hline Organizations & Web link \\
\hline Tennessee Beekeeper's association (TBA) & http://www.tnbeekeepers.org/ \\
\hline The Florida State Beekeepers Association & http://www.floridabeekeepers.org/ \\
\hline American beekeeping federation (ABF) & http://www.abfnet.org/ \\
\hline African beekeeping resource center & http://apiconsult.com/ \\
\hline $\begin{array}{l}\text { European Professional Beekeepers } \\
\text { Association (EPBA) }\end{array}$ & http://www.professional-beekeepers.eu/ \\
\hline British Beekeepers Association & http://www.bbka.org.uk/ \\
\hline Beekeeping Development in Moldova. & http://outdoorplace.org/beekeeping/moldova.htm \\
\hline Beekeeping Development in Ukraine & http://www.honeyo.com/org-International.shtml \\
\hline Beekeeping Development in Fiji. & http://outdoorplace.org/beekeeping/peace.htm \\
\hline Bees for Development & http://www.beesfordevelopment.org/ \\
\hline Eastern Apicultural Society (EAS) & بttp://easternapiculture.org/ \\
\hline $\begin{array}{l}\text { Honey Packers and Marketers Association } \\
\text { of Australia. }\end{array}$ & http://www.honeybee.com.au/ \\
\hline $\begin{array}{l}\text { International Bee Research Association } \\
\text { (IBRA) }\end{array}$ & http://www.ibrabee.org.uk/ \\
\hline Japanese Honey Bee Association & http://www.nihon-bachi.org/english/f2.htm \\
\hline Apiculture New Zealand & http://apinz.org.nz/ \\
\hline $\begin{array}{c}\text { Uganda national Apiculture development } \\
\text { organization (TUNADO) }\end{array}$ & ://www.tunadobees.org/ \\
\hline
\end{tabular}

\section{Economic importance or income source}

Economic value of honey bee is a global concern in this century [48]. Bee product, honey has high importance globally with respect to income source, by an estimation there is about 6 billion \$US annually earning in global market [10]. Rural people's income source depends upon many types of assets $[11,49]$. An analysis of family member's occupation in Chitwan district Nepal is reported by [24] and concluded that the $54 \%$ family members occupation is agriculture, $25 \%$ are students, only small number $2.55 \%$ in business, $6 \%$ in services and 13\% (Fig. 1) are in abroad services [24].

It means that large population is attached with agriculture sector not only in Nepal but also in some other countries. Therefore, by beekeeping practice we can improve our income source and rural livelihood [11]. Beekeeping is prime development tool and an additional source of wealth for farmer communities by different bee products especially the commercial vast use of honey bee become a business globally in recent era [50, 51]. Large number of peoples are employed in beekeeping services, in 2012, 2,552 individuals are employed in U.S for beekeeping [35]. It is an immense source of raising income for both men and women e.g. in Kenya and in some other countries where women are empowered by different activities [42]. In some countries there are also beekeeper trainers such as Society of facilitator and Trainer (SOFT) which give training but rare [52]. In Zimbabwe there are many beekeeping projects are initiated by NGO's which will act as a milestone for raising economy. Women can use the different beekeeping materials for making secondary products. In an analysis of income by beekeeping in Chitanga village, Mwenezi District, Zimbabwe concluded that by beekeeping villagers collect (20 liters) raw 
honey and packed it into (350 milliliters) bottles and sold in US\$3.50-\$5.00 each bottle. By this the annual income range of villagers is about US\$180.00-\$380.00 that is greater than one tone of maize production that is US\$285.00 [11]. In 2000, U.S earns $\$ 14.6$ billion from crops due to pollination service by honey bees [6, 36] and in 2010 it is estimated that there is about $\$ 16.4$ billion contribution by insect pollinators out of which $\$ 12.4$ billion is due to honey bees [53]. Many western countries farmers take bees on rent at their prescribed rates for pollination service from beekeepers. Their rents(fees) are increasing day by day and it is a great economic benefit for beekeepers in Soviet bloc countries honey bees are consider as second currency due to earning from honey production $[18,35]$.

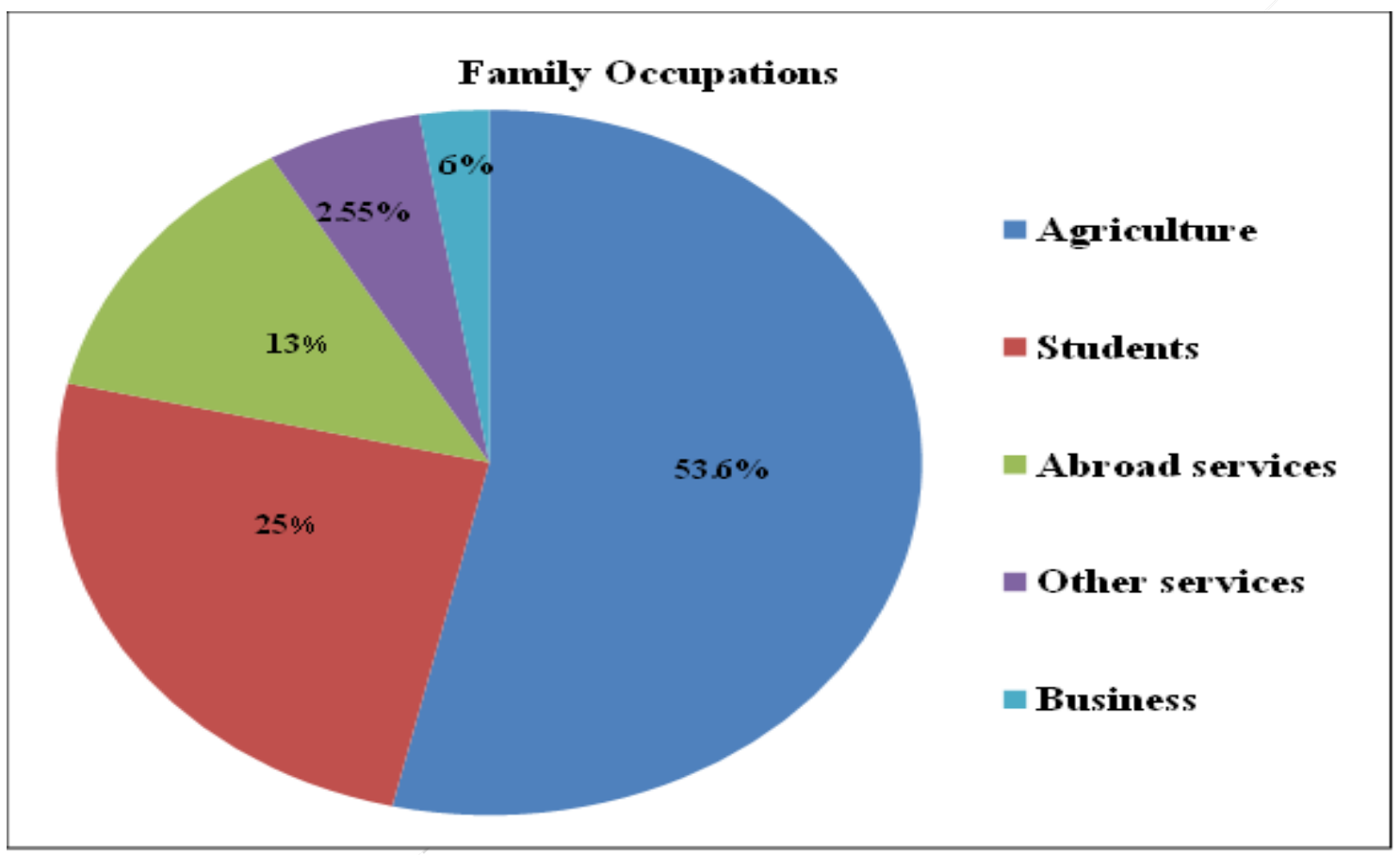

Figure 1. Family occupations in Chitwan district Nepal [24]

\section{Honey bee sting}

Honey bee have stinger it can sting the predator or person as defense strategy for themselves or colony. Its sting is very annoying, and causes localize pain, redness and swelling. It is not a major therapeutic dilemma for about $99 \%$ peoples, but it is a great threat to persons who are very sensitive to bee venom because it is a cause of allergic reaction. Hymenoptera sting basis allergic reactions are about $0.3-3.5 \%$ in adult population [22].

\section{Threats to honey bee}

There are lot of stress on honey bee colonies in all regions of the world therefore honey bee colonies are gradually declining (Table 2).

In 2006 , according to a study $30 \%$ to $90 \%$ colonies are declined in USA due to these threats still the decline is continuing [56]. These threats cause serious economic loss throughout the world [18] There is a great honey bee colonies loss in summer seasons due to harsh weather conditions in different areas and regions. So, the selection of area is very important for beekeepers for avoiding 
loss. In Saudi Arabia summer season is big hurdle for beekeepers when temperature reaches up to $45^{\circ} \mathrm{C}$. Most suitable area can be selected by geographical information system by constructing a map [46]. Due to these threats number of honey bee colonies in U.S since 1970s that are greater than 4 million decreases into 2.41 million and further decrease since 2006 [6, 32]. Despite these threats honey bee colonies are losses by difference in beekeeping practice [18].

Table 2. There are some common threats to honey bee colony depletion

\begin{tabular}{|c|c|c|}
\hline Threats & Examples & References \\
\hline Poor nutrition & pollen or nectar scarcity & {$[53,54]$} \\
\hline Parasites & $\begin{array}{c}\text { Varroa destructor, wax moth, Acarapis woodi, Apocephalus } \\
\text { borealis, }\end{array}$ & $\begin{array}{l}{[18,19,53,} \\
55,56]\end{array}$ \\
\hline Parasitic Fungi & $\begin{array}{c}\text { Ascosphaera Apis, Aspergillus niger, Nosema ceranae and Nosema } \\
\text { apis }\end{array}$ & $\begin{array}{c}{[18,23,33,} \\
53,57]\end{array}$ \\
\hline Viruses & $\begin{array}{l}\text { Acute bee paralysis virus (ABPV), Deformed wing virus (DWV), } \\
\text { Kashmir bee virus (KBV) and Israeli acute bee paralysis virus } \\
\text { (IAPV), Black queen cell virus (BQCV), Chronic bee paralysis virus } \\
\text { (CBPV), Schmallenberg virus (SBV), they cause many diseases in } \\
\text { bees having weak immune system. }\end{array}$ & {$[18,53,58]$} \\
\hline Bacteria & $\begin{array}{l}\text { Acid-Fast Bacilli (AFB), European foulbrood (EFB), septicemia and } \\
\text { spiroplasma, Melissococcus plutonius }\end{array}$ & {$[18,33,53]$} \\
\hline Pests & Beetles, skunks, raccoons, bears, and mice & [53] \\
\hline Pesticides & $\begin{array}{c}\text { Insecticide: } \\
\text { Acephate, Carbaryl, Cypermethrin, Deltamethrin, Diazinon, } \\
\text { Dimethoate, Imidacloprid, Lamda-cyhalothrin, Malathion, } \\
\text { Methomyl, Permethrin, Phosmet, Pyridaben, Spinosad, Thiacloprid, } \\
\text { Tiamethoxam, Acetamiprid, Chlorpyrifos, Endosulfan, Phosalone, } \\
\text { Clofentezine, Formetanate, Pyrimicarb etc. } \\
\text { Acaricides: } \\
\text { Bifenazate, Dicofol, Spiromesifen etc. } \\
\text { Fungicides: } \\
\text { Fenastrobin, Boscalid, Captan, Chlorothalonil, Cymoxanil, } \\
\text { Fenamidone, Iprodione, Mancozeb, Myclobutanil, Pyraclostrobine, } \\
\text { Pyrimethanil, Zineb, Zoxamide etc. } \\
\text { Herbicides: } \\
\text { 2, 4 D, Clomazone, Chlopyralid, Fluazifop-p-butyl, Glyphosate, } \\
\text { Linuron, Metribuzin, Paraquat, Trifluralin etc. } \\
\text { And others include } \\
\text { organochlorine, carbamate, }\end{array}$ & {$[59,60]$} \\
\hline $\begin{array}{l}\text { Climatic } \\
\text { changes }\end{array}$ & $\begin{array}{c}\text { Drought, increasing or decreasing temperatures, changes in rainfall, } \\
\text { Wind }\end{array}$ & {$[35,51,61]$} \\
\hline
\end{tabular}

\section{Conclusion and Recommendations}

After this through study it is concluded that tiny creatures, honey bees have great importance in our lives due to their thousands of services including bee products (Honey, bee wax, propolis, royal jelly etc) and ecosystem services such as pollination and help in raising our livelihoods. Recently pollination service is declining due to many threats especially diseases which is very alarming situation because many crops of our agriculture sectors depend upon them. If 
pollinators are vanishing so we will deprive of our food. Beekeeping is large sector for earning, but it requires the awareness and good beekeeping practices. Beekeeping practice including floral condition of particular area, types of honey bee of that area, bee Biology, bee keeping tools, handling practice of honey bees, seasonal management for colonies, awareness about honey bee diseases and its management. In current scenario there is lacking beekeeping practices and especially gender wise discrimination otherwise, it is huge sector for earning livelihood for developing countries so, there is an enormous need to pay attention to this sector. More researches should be done for highlighting the economic value of Honey bees. There is an immense need to give awareness to peoples that how they raise their livelihoods by beekeeping practice. Government and NGO's should take collaborative steps for new policy and planning for beekeepers. Besides this there should be funding source for beekeepers to increase this eco-friendly culture.

\section{Authors' contributions}

Conceived the idea: MF Malik, Wrote the Paper: S Naz \& MF Malik, Proofread the data: M Hussain, S Afsheen \& R Iqbal, Corresponding author: $\mathrm{S} \mathrm{Naz}$

\section{References}

1. Eban-Rothschild A \& Bloch G (2015). The colony environment modulates sleep in honey bee workers. J of Exper Biol 3: 404-411.

2. De Oliveira SA, dos Santos EB \& de Nardi Junior G (2013). Implantação da associação dos Apicultores e da criação da "casa do mel" em botucatu-sp. Tekhne e Logos 3: 43-55.

3. Nunes LA, Araújo EDD, Marchini LC \& Moreti AC (2012). Variation morphogeometrics of Africanized honey bees (Apis mellifera) in Brazil. Iheringia Série Zool 3: 321-326.
4. Rogers SR, Tarpy DR \& Burrack HJ (2014). Bee species diversity enhances productivity and stability in a perennial crop. PloS One 5: e97307.

5. Breeze TD, Bailey AP, Balcombe KG \& Potts SG (2011). Pollination services in the UK: How important are honeybees. Agric, Ecosys \& Environ 3: 137-143.

6. Greenleaf SS \& Kremen C (2006). Wild bees enhance honey bees' pollination of hybrid sunflower. Proc of the Nat Acad of Sci 37: 13890-13895.

7. El-Aidy WK, Ebeid AA, Sallam AERM, Muhammad IE, Abbas AT, Kamal MA \& Sohrab SS (2015). Evaluation of propolis, honey, and royal jelly in amelioration of peripheral blood leukocytes and lung inflammation in mouse conalbumininduced asthma model. Saudi J of Biol Sci 6: 780-788.

8. Ali MAASM (2012). Studies on bee venom and its medical uses. Inter $J A d v$ Res Technol 2: 69-83.

9. VanEngelsdorp D \& Meixner MD (2010). A historical review of managed honey bee populations in Europe and the United States and the factors that may affect them. J of Inver Pathol 103: S80S95.

10. Ajibola A, Chamunorwa JP \& Erlwanger KH (2012). Nutraceutical values of natural honey and its contribution to human health and wealth. Nutr \& Metabol 1: 1 .

11. Chazovachii B, Chuma M, Mushuku A, Chirenje L, Chitongo L \& Mudyariwa R (2013). Livelihood resilient strategies through beekeeping in Chitanga village, Mwenezi District, Zimbabwe. Sust Agric Res 1: 124.

12. da Silva IAA, da Silva TMS, Camara CA, Queiroz N, Magnani M, de Novais JS, Soledade LEB, de Oliveira Lima E, de Souza AL \& de Souza AG (2013). Phenolic profile, antioxidant activity and 
palynological analysis of stingless bee honey from Amazonas, Northern Brazil. Food Chem 4: 3552-3558.

13. El Sohaimy SA, Masry SHD \& Shehata MG (2015). Physicochemical characteristics of honey from different origins. Ann of Agric Sci 2: 279-287.

14. Nayik GA, Suhag Y, Majid I \& Nanda V (2016). Discrimination of high-altitude Indian honey by chemometric approach according to their antioxidant properties and macro minerals. $J$ of the Saudi Soc of Agric Sci.

15. McLoone P, Warnock M \& Fyfe L (2016). Honey: A realistic antimicrobial for disorders of the skin. $J$ of Microbiol, Immunol and Inf 2: 161-167.

16. Safitri E, Utama S, Widiyatno TV, Sandhika W \& Prasetyo RH (2016). Auto-regeneration of mice testicle seminiferous tubules due to malnutrition based on stem cells mobilization using honey. Asian Pacific J of Reprod 1: 3135.

17. Li S, Chen G, Zhang C, Wu M, Wu S \& Liu Q (2014). Research progress of natural antioxidants in foods for the treatment of diseases. Food Sci and Human Wellness 3: 110-116.

18. Genersch E (2010). Honey bee pathology: current threats to honey bees and beekeeping. Appl Microbiol and Biotechnol 1: 87-97.

19. Simone-Finstrom M \& Spivak M (2010). Propolis and bee health: the natural history and significance of resin use by honey bees. Apidol 3: 295-311.

20. Bogdanov S (2011). Royal jelly, bee brood: composition, health, medicine: a review. Lipids 8: 8-19.

21. Salkova DS, Panayotova-Pencheva MS \& Movsesyan SO (2015). Some bee products as antiparasitic remedies. Russ Parasitol J 1: 75-78.

22. Frick M, Fischer J, Helbling A, Ruëff F, Wieczorek D, Ollert M, Pfützner W,
Müller S, Huss-Marp J, Dorn B, Biedermann T, Lidholm J, Ruecker G, Bantleon F, Miehe M, Spillner E \& Jakob $T$ (2016). Predominant Api m 10 sensitizations as risk factor for treatment failure in honey bee venom immunotherapy. $J$ of Aller and Clin Immunol.

23. Foley K, Fazio G, Jensen AB \& Hughes WO (2014). The distribution of Aspergillus spp. opportunistic parasites in hives and their pathogenicity to honey bees. Vet Microbiol 3: 203-210.

24. Devkota K, Dhakal SC \& Thapa RB (2016). Economics of beekeeping as pollination management practices adopted by farmers in Chitwan district of Nepal. Agric \& Food Sec 1: 1.

25. Gallant AL, Euliss Jr NH \& Browning Z (2014). Mapping large-area landscape suitability for honey bees to assess the influence of land-use change on sustainability of national pollination services. PloS One 6: e99268.

26. Garibaldi LA, Steffan-Dewenter I, Kremen C, Morales JM, Bommarco R, Cunningham SA, Carvalheiro LG, Chacoff NP, Dudenhoeffer JH, Greenleaf SS, Holzschuh A, Isaacs R, Krewenka K, Mandelik Y, Mayfield MM, Morandin LA, Potts SG, Ricketts TH, rgyi HS, Viana BF, Westphal C, Winfree R \& Klein AM (2011). Stability of pollination services decreases with isolation from natural areas despite honey bee visits. Ecol Let 10: 1062-1072.

27. Polce C, Termansen M, AguirreGutiérrez J, Boatman ND, Budge GE, Crowe A, Garratt MP, Pietravalle S, Potts SG, Ramirez JA, Somerwill KE \& Biesmeijer JC (2013). Species distribution models for crop pollination: a modelling framework applied to Great Britain. PloS One 10: e76308.

28. Garibaldi LA, Steffan-Dewenter I, Winfree R, Aizen MA, Bommarco R, 
Cunningham SA, Kremen C, Carvalheiro LG, Harder LD, Afik O, \& et al. (2013). Wild pollinators enhance fruit set of crops regardless of honey bee abundance. Sci 6127: 1608-1611.

29. Kremen C, Williams NM and Thorp RW (2002). Crop pollination from native bees at risk from agricultural intensification. Proc of the Nat Acad of Sci 26: 16812-16816.

30. Klein AM, Vaissiere BE, Cane JH, Steffan-Dewenter I, Cunningham SA, Kremen C \& Tscharntke T (2007). Importance of pollinators in changing landscapes for world crops. Proc of the Royal Soc of Lon B: Biol Sci 1608: 303313.

31. Aizen MA \& Harder LD (2009). The global stock of domesticated honey bees is growing slower than agricultural demand for pollination. Cur Biol 11:915918.

32. Winfree R, Gross BJ \& Kremen C (2011). Valuing pollination services to agriculture. Ecol Econ 71: 80-88.

33. Bencsik M, Le Conte Y, Reyes M, Pioz M, Whittaker D, Crauser D, Delso NS \& Newton MI (2015). Honeybee Colony Vibrational Measurements to Highlight the Brood Cycle. PloS One 11: 0141926.

34. Hendriksma HP, Küting M, Härtel S, Näther A, Dohrmann AB, SteffanDewenter I \& Tebbe CC (2013). Effect of stacked insecticidal Cry proteins from maize pollen on nurse bees (Apis mellifera carnica) and their gut bacteria. PloS One 3: e59589.

35. Bond J, Plattner K \& Hunt K (2014). Fruit and Tree Nuts Outlook: Economic Insight. US Pollination-Services Market. USDA Econ Res Ser Situ and Outlook FTS-357SA.

36. Chatterjee A, Chatterjee S, Smith B \& Basu P (2019). Determinants of Bee Visitation in an Economically Important Vegetable Crop Along an Agricultural
Intensification Gradient. In Proc of the Zool Soc (1-7).

37. Petersen JD, Reiners $S$ and Nault BA (2013). Pollination services provided by bees in pumpkin fields supplemented with either Apis mellifera or Bombus impatiens or not supplemented. PloS One 7: e69819.

38. Buri P, Humbert JY \& Arlettaz R (2014). Promoting pollinating insects in intensive agricultural matrices: field-scale experimental manipulation of haymeadow mowing regimes and its effects on bees. PloS One 1: e85635.

39. Kjøhl M, Nielsen A \& Stenseth NC (2011). Potential effects of climate change on crop pollination. Food and Agriculture Organization of the United Nations (FAO).

40. Crenna E, Sala S, Polce C \& Collina E (2016). Pollinators in life cycle assessment: towards a framework for impact assessment. J of Cleaner Prod.

41. Kanniainen V, Lehtonen $\mathrm{T}$ \& Mellin I (2013). Honeybee EconomicsImplications for Ecology Policy.

42. Mburu P, Affognon H, Irungu P, Mburu J \& Raina S (2015). Beekeeping for Women Empowerment: Case of Commercial Insect Programme in Kitui County Kenya. IAFFE.

43. Mudzengi C, Kapembeza C S, Dahwa E, Taderera L, Moyana S \& Zimondi M (2020). Ecological Benefits of Apiculture on Savanna Rangelands. Bee World 97: 17-20.

44. Singh I \& Singh S (2018). Honey moisture reduction and its quality. $J$ of food Sci and Technol 55: 3861-3871.

45. Al-Ghamdi A, Adgaba N, Getachew A \& Tadesse Y (2016). New approach for determination of an optimum honeybee colony's carrying capacity based on productivity and nectar secretion potential of bee forage species. Saudi J of Biol Sci 1: 92-100. 
46. Abou-Shaara HF, Al-Ghamdi AA \& Mohamed AA (2013). A suitability map for keeping honey bees under harsh environmental conditions using Geographical Information System. World Appl Sci J 8: 1099-1105.

47. Adgaba N, Al-Ghamdi A, Shenkute AG, Ismaiel S, Al-Kahtani S, Tadess $\mathrm{Y}$, Ansari MJ, Abebe W \& Abdulaziz MQA (2014). Socio-economic analysis of beekeeping and determinants of box hive technology adoption in the Kingdom of Saudi Arabia. JAPS: J of Ani \& Plant Sci 6.

48. Gill RA (1990). August. The value of honeybee pollination to society. In VI Inter Symp on Poll 288: 62-68).

49. Bradbear N (2009). Bees and their role in forest livelihoods: a guide to the services provided by bees and the sustainable harvesting, processing and marketing of their products. Non-wood Forest Prod 19.

50. Jaffé R, Pope N, Carvalho AT, Maia UM, Blochtein B, de Carvalho CAL, Carvalho-Zilse GA, Freitas BM, Menezes C, de Fátima Ribeiro $M$, Venturieri GC \& Imperatriz-Fonseca VL (2015). Bees for development: Brazilian survey reveals how to optimize stingless beekeeping. PloS One 3: e0121157.

51. Belie T (2009). Honeybee production and marketing systems, constraints and opportunities in Burie District of Amhara Region, Ethiopia (Doctoral dissertation, Bahir Dar University).

52. Qaiser T, Ali M, Taj S \& Akmal N (2013). Impact assessment of beekeeping in sustainable rural livelihood. $J$ of Soc Sci (COES\&RJ-JSS) 2.

53. Johnson R \& Corn ML (2014). Bee health: Background and issues for congress. Congr Res Ser 7-5700.

54. Champetier A, Sumner DA \& Wilen JE (2015). The bioeconomics of honey bees and pollination. Environ and Reso Econ 1: 143-164.

55. Neumann P \& Carreck NL (2010). Honey bee colony losses. J of Apic Res 1: 1-6.

56. Ellis JD, Evans JD \& Pettis J (2010). Colony losses, managed colony population decline, and Colony Collapse Disorder in the United States. J of Apic Res 1: 134-136.

57. Jack CJ, Uppala SS, Lucas HM \& Sagili RR (2016). Effects of pollen dilution on infection of Nosema ceranae in honey bees. J of Ins Physiol 87: 12-19.

58. Brutscher LM, Daughenbaugh KF \& Flenniken ML (2015). Antiviral defense mechanisms in honey bees. Cur Opin in Ins Sci 10: 71-82.

59. Lu C, Warchol KM and Callahan RA (2012). In situ replication of honey bee colony collapse disorder. Bull of Insectol 1: 99-106.

60. Rişcu (Jivan) A \& Bura M (2013). The Impact of Pesticides on Honey Bees and Hence on Humans. Scientific Papers: Animal Science \& Biotechnologies/ Lucrari Stiintifice: Zootehnie Si Biotehnologii 2.

61. Tirado R, Simon G \& Johnston P (2013). Bees in decline: A review of factors that put pollinators and agriculture in Europe at risk. Greenp Res Lab Tech Rep (Rev) pp.1-48. 